J. Product. \& Dev., 16(3):483 - 506(2011)

\title{
EFFECT OF FOLIAR SPRAY WITH ZINC AND BORON ON GROWTH, YIELD AND FRUIT QUALITY OF STRAWBERRY (Fragaria $\times$ ananassa Duch cv. Camarosa) PLANTS GROWN IN SANDY SOIL
}

\section{I.A.S. Al-Esaily}

Hort. Research Institute, Agriculture Research Center, Giza, Egypt

\section{ABSTRACT}

This experiment was carried out during the two successive summer seasons of 2009/2010 and 2010/2011 at EL-Kassasien Horticultural Research Station, Ismailia Governorate, Egypt, to study the effect of foliar application with $\mathrm{ZnSO}_{4}$ at rates of 0,150 and $200 \mathrm{mg} / \mathrm{l}$ as and boric acid $\mathrm{H}_{3} \mathrm{BO}_{3}$ (17\% boron)at rates 0,100 and $150 \mathrm{mg} / \mathrm{l}$ on vegetative growth, photosynthetic pigments, chemical constituents in branches and fruit, yield productivity, fruit quality at harvest time Strawberry plants (Fragaria $\times$ ananassa Duch cv. Camarosa) grown under sandy soil conditions with drip irrigation system.

Result showed that spraying strawberry plant with $150 \mathrm{mg} / \mathrm{l}$ $\mathrm{ZnSO}_{4}$ or $150 \mathrm{mg} / \mathrm{H}_{3} \mathrm{BO}_{3}$ significantly increased all studied parameters, such as vegetative plant growth, early and total yield as well as fruit quality in both seasons as compared to control treatment $(0 \mathrm{mg} / \mathrm{l})$, which recorded the lowest values of all studied parameters. In generally, spraying plants with $150 \mathrm{mg} / \mathrm{l} \mathrm{ZnSO}_{4}+150 \mathrm{mg} / \mathrm{l} \mathrm{H}_{3} \mathrm{BO}_{3}$ gave the best results for increasing plant growth, yield and its components as well as fruit quality, i.e., Vit. C, TSS and total sugar in both seasons as compared other interaction treatments.

Conclusively, application of $\mathrm{ZnSO}_{4}$ or $\mathrm{H}_{3} \mathrm{BO}_{3}$ at $150 \mathrm{mg} / \mathrm{l}$ of each alone or mixture improved vegetative growth in the tested plants and increased yield and fruit quality.

Keywords: Strawberry, zinc, boron, $\mathrm{ZnSO}_{4}, \mathrm{H}_{3} \mathrm{BO}_{3}$, early \& total yield, and fruit quality.

\section{INTRODUCTION}

Strawberries are ideal model for nutrient interaction studies in perennial crops. Since, they are relatively precocious in producing their first crop within months of planting, and also, they can easily be excavated and divided into 
vegetative and reproductive components, allowing for detailed evaluation of observed growth or responses (May and Pritts, 1993).

The total area devoted for production in the year of 2010 in Egypt was about 5245 ha. Which produced 238432 ton with average 45.458 ton/ha. The export quantity of strawberry in Egypt was about 66992 tons in the year of 2009 (Faostat, 2010).

Balanced nutrient at proper time is one of the means to reach a commercial fruit production, and improved yield and fruit quality. Foliar program at key stages can have a marked positive effect on fruit yield and quality. Micronutrients have considerable significant effect, as limiting factors, on the productivity of strawberry. While, their deficiencies are more frequent in many soil types such as sandy soil. Micronutrients such as $\mathrm{Zn}$ and B are elements with specific and essential physiological functions in plant metabolism and they are required for normal development and growth of plants in minute quantities. Micronutrients are very efficient and minute quantities produced optimum effects, even a light deficiency or excess, on the other hand, are harmful to the plant (Reddy and Reddi,1998).

Zinc is a component of many enzymes such as dehydrogenase , proteinase, peptidases and phosphohydrolass important for (metabolism of carbohydrate, protein and phosphate). ( Kabata and Pendias, 1992; Srivastava and Gupta, 1996).

Among nutrient elements, zinc and boron have important role on pollination, fruit set and total yield (Motesharezade et al., 2001). Zinc is known to have an important role either as a metal component of enzymes or as a functional, structural or regulatory factor of a large number of enzymes (Bowler et al., 1994). Zinc induces pollen tube growth through, its role on tryptophan as an auxin precursor biosynthesis (Chaplin and Westwood, 1980). Growth of the receptacle is controlled primarily by auxin, which is synthesized in achene's (Archbold and Dennid, 1984), therefore $\mathrm{ZnSO} 4$ is applied to increase number of leaves/ plant, fruit number, size and quality. Zinc sulphate permits normal development of new leaves (Barker and Pilbeam, 2006) and Abdollah et al. (2012). Zinc has also shown to have an important role in photosynthesis and related enzymes, resulting in increasing sugar and decreasing acidity (Abedy, 2001).

Another nutrient which also has an important role in fruit quality is boron. Boron has an effect on cell wall structure and also has a major effect on cell elongation (pollen tube) and root growth (Barker and Pilbeam, 2006). Boron is also involved in transport of sugars and in synthesis of cell wall 
materials, cell division and differentiation, carbohydrate metabolism , formation and synthesis of protein (Marschner,1995).

Zuhair et al. (2010) found that, the highest increases in leaf area , percentage of flower set and average weight of fruit recorded by foliar application of $20 \mathrm{mg} / \mathrm{l}$ of boron, but the highest yield per plant and total yield obtained by application $0 \mathrm{mg} / \mathrm{L}$ boron on Hapil cultivars plants. While application of $30 \mathrm{mg} / \mathrm{l}$ of boron on Kaiser's samling plants gave the best result in percentage of leaf dry weight and total soluble solids in fruits of strawberry. Abdollah et al., (2010 and 2012) found that the highest number of fruit clusters, TSS and vitamin $\mathrm{C}$ in fruit of strawberry was obtained through application of a combination of $\mathrm{ZnSO}_{4} 200 \mathrm{mg} / 1 \times \mathrm{H}_{3} \mathrm{BO}_{3}$ at $300 \mathrm{mg} / \mathrm{l}$.

So, the present work aimed to maximize the productivity of Strawberries through application of some micro-elements under sandy soil conditions.

\section{MATERIALS AND METHODS}

This experiment was carried out during the two successive summer seasons of 2009/2010 and 2010/2011 at EL-Kassasien Horticultural Research Station, Ismailia Governorate, Egypt, to study the effect of foliar spray of three concentration of $\mathrm{ZnSO}_{4}(0,100$ and $150 \mathrm{mg} / \mathrm{l})$ and three boric acid (17\% boron ) concentration $(0,150$ and $200 \mathrm{mg} / \mathrm{l})$ as on vegetative growth,yield and fruit quality of strawberry (Fragaria $x$ ananassa Duch. cv. Camarosa ). The physical and chemical analysis of the soil are presented in Table 1.

Table 1: The physical and chemical properties of the experimental soil

\begin{tabular}{|l|c|c|l|c|c|}
\hline \multicolumn{3}{|c|}{ Physical properties } & \multicolumn{3}{c|}{ Chemical properties } \\
\hline & $\mathbf{2 0 0 9}$ & $\mathbf{2 0 1 0}$ & & $\mathbf{2 0 0 9}$ & $\mathbf{2 0 1 0}$ \\
\hline Sand \% & 94.6 & 95.5 & Organic matter(\%) & 0.08 & 0.03 \\
Silt \% & 2.6 & 3.7 & Available N (\%) & 6.2 & 5.8 \\
Clay \% & 2.8 & 1.8 & Available P(ppm) & 5.9 & 5.3 \\
Texture & sandy & sandy & Available K (ppm) & 64 & 51 \\
Available Zn (ppm) & 3.25 & 3.22 & Calcium carbonate(\%) & 0.29 & 0.23 \\
\hline
\end{tabular}

This experiment included 9 treatments, which were the combination between three concentration of zinc sulfate at 0,100 and $150 \mathrm{mg} / \mathrm{l}$ and three concentration boric acid (17\% boron) at 0,150 and $200 \mathrm{mg} / \mathrm{l}$.

These treatments were arranged in a split plot design with three replications. Zinc sulphate concentrations were assigned at random in the main plots, while, sub plots were devoted to boric acid concentrations. 
Frigo transplants of strawberry Camarosa cultivar were obtained from local nurseries. The transplants were dipped for 10 minutes at doses of $1 \mathrm{~g} / \mathrm{L}$ Benlet $+1 \mathrm{~g} / \mathrm{L}$ Rizolex.. The transplants were planted on one side of row at 13 and $12^{\text {th }}$ Sept. in 2009 and 2010, respectively. Plants were sprayed three times at age 30, 45 and 60 days after planting, The experimental unit area was $21 \mathrm{~m}^{2}$ and each unit contained six rows with $5 \mathrm{~m}$ length for each and $70 \mathrm{~cm}$ width of them, four inner rows were possessed for yield determination, whereas the two outer rows were devoted to plant growth parameter. The distance between seedlings was $15 \mathrm{~cm}$. One row was left between two experimental units to avoid the overlapping.

The ammonium nitrate $(33.5 \% \mathrm{~N})$ at rates of $200 \mathrm{~kg} \mathrm{~N} / \mathrm{fed}$. was added through the drip irrigation system during the growing season. Calcium super phosphate $\left(15.5 \% \quad \mathrm{P}_{2} \mathrm{O}_{5}\right)$ at the rate of $46.5 \mathrm{~kg} / \mathrm{fed}$. and potassium sulphate ( 48 $\% \mathrm{~K}_{2} \mathrm{O}$ ) at the rate of $80 \mathrm{~kg} / \mathrm{fed}$. were added once during soil preparation. While during the entire growing season, phosphorus and potassium fertilizers were also added through the drip irrigation system four times per week, at the rate of $75 \mathrm{~kg} \mathrm{P}_{2} \mathrm{O}_{5} / \mathrm{fed}$. in the form of phosphoric aid $\left(80 \% \mathrm{P}_{2} \mathrm{O}_{5}\right)$ and $120 \mathrm{~kg}$ $\mathrm{K}_{2} \mathrm{O}$ as soluble potassium sulphate $\left(48 \% \mathrm{~K}_{2} \mathrm{O}\right)$. The normal agricultural practices of strawberry production under drip irrigation system of this area were followed according to the recommendations of Agriculture Ministry.

\section{Data recorded}

\section{Plant growth characters}

A random sample of three plants from each experimental units was taken at flower initiation stage 100 days after transplanting in the two growing seasons to measure the following parameters: Number of leaves/plant, leaf area/plant, fresh weight/plant (gm). Fresh weight /plant were dried at $70 \mathrm{C}^{\mathrm{o}}$ till constant weight and dry weight/plant was calculated.

\section{Photosynthetic pigments.}

In this experiment a disc sample from the fourth upper leaf on the main vine was randomly taken from every plot at 100 after transplanting and determine chlorophyll a, b, $(\mathrm{a}+\mathrm{b})$ and carotenoids according to the method described by Wettestein (1957).

\section{Contents of $N, P$ and $K(\%)$ : In branches and fruits}

The dry weight of branches and fruits at harvesting time were finely ground and wet digested for N, P and K Contents in branches and fruits: Total nitrogen, phosphorus and potassium percentages in shoots and fruits were determined in dry matter according to the both methods described by A.O.A.C. (1995). 


\section{Early yield and its components:}

An average berry weight(gm), berry yield/plant (gm), No. of berry/ plant, berry yield/fed (ton) were calculated (as fresh weight of harvested fruits from the first four pickings ).

\section{Total yield and its components:}

An average berry weight (gm), berry yield/ plant (gm), No. of berry / plant, berry yield/ fed. (ton) were calculated as fresh weight of all harvested fruit all over growing seasons.

\section{Fruit Quality:}

Random samples of ten fresh fruits were taken from each plot at the peak of harvesting period to determine :

a-Total soluble sugars (\%): It was determined according to the both method described by Forsee (1938).

b - Total soluble solid (T.S.S): It was determined with the help of hand refract meter,

c- The acidity: It was estimated by titrating known volume of juice against 0.1 $\mathrm{N} \mathrm{NaOH}$ using phenolphthalein as an indicator,

d- Ascorbic acid (vitamin C): It was determined by volumetric method through standard dye solution (Sadasivam and Thymoli 1987).

\section{Statistical analysis:}

Recorded data were subjected to the statistical analysis of variance according to Snedecor and Cochran (1980), and means separation were done according to LSD at $5 \%$ level.

\section{RESULTS AND DISCUSSION}

\section{Plant growth characters:}

Results given in Table 2 show the effect of spraying plants with 0,150 and $200 \mathrm{mg} / \mathrm{l}$ as $\mathrm{ZnSO}_{4}$ and boron at rates of 0,100 and $150 \mathrm{mg} / \mathrm{l}$ as boric acid (17\% boron ) and different combination treatments among them as well as water spray (control) on growth aspects (number of leaves/plant, leaf area, fresh and dry weight/plant). It is obvious that vegetative growth was promoted with all spraying materials as compared to control.

Spraying plants with $150 \mathrm{mg} / 1 \mathrm{ZnSO}_{4}$ recorded the uppermost values of number of leaves/plant, leaf area, fresh and dry weight/plant than control treatments. Spraying with zinc had a positive effect on vegetative growth, this 
AL- ESAILY 
may be due to that $\mathrm{Zn}$ deficiency was a significant decrease in ${ }^{14} \mathrm{C}$ fixed in the primary photosynthetic process (Srivastava and Gupta 1996), so spraying plants with $\mathrm{Zn}$ increased photosynthetic efficiency, which reflected a simulative effect on vegetative growth of pepper plant, and also zinc is a component of a variety of enzymes such as dehydrogenase, proteinase, peptidase and phosphohydrases (metabolism of carbohydrates, protein and phosphate), and $\mathrm{Zn}$ is known to stimulate plant resistance to dry and hot weather (Kabata and Pendias, 1992)

Spraying plants with $150 \mathrm{mg} / 1$ boric acid (17.8\%) significantly increased number of leaves/plant, leaf area, fresh and dry weight/plant than other treatments. Boron have considerable significant effect, as limiting factor, on the productivity of strawberry. Boron has an effect on cell wall structure and also has a major effect on cell elongation (pollen tube) and root growth (Barker and Pilbeam, 2006). Also, boron is element with specific and essential physiological functions in plant metabolism and they are required for normal development and growth of plants in minute quantities (Reddy and Reddi, 1998).

The best treatment for increasing number of leaves/plant, leaf area, fresh and dry weight/plant was spraying plants with $150 \mathrm{mg} / 1 \mathrm{Zn} \mathrm{SO} 4+150 \mathrm{mg} / \mathrm{l}$ boric acid as compared to other treatments (Table 3). The obtained results are in accordance with those reported (Kabata and Pendias, 1992; Srivastava and Gupta, 1996 and Motesharezade et al., 2001).

\section{Photosynthetic pigments}

Concerning the effect of spraying plants with 150 and $200 \mathrm{mg} / 1 \mathrm{ZnSO}_{4}$ and 100 and $150 \mathrm{mg} / 1$ boric acid $(17 \% \mathrm{~B})$ and different combination treatments among them as well as water spray (control) on chlorophyll a , b, total ( $a+b)$ and carotenoids in strawberry leaves in both seasons, it is obvious form Table 4 that all spraying treatments had a significantly increments in yield and its components as compared to control.

The obtained results in Table 4 show that, spraying of strawberry plants with $\mathrm{ZnSO}_{4}$ concentration of $150 \mathrm{mg} / \mathrm{l}$ had a significant effect on the concentration of chlorophyll $\mathrm{a}, \mathrm{b}$, total $(\mathrm{a}+\mathrm{b})$ and carotenoids in both seasons. It is clear from data that foliar spray with concentration of $150 \mathrm{mg} / \mathrm{l}$ recorded the highest values of chlorophyll $\mathrm{a}, \mathrm{b}$, total $(\mathrm{a}+\mathrm{b})$ and carotenoids in both seasons. These results are in harmony with those reported by Ahmad (2002) and Abedy (2001) who found that chlorophyll a, b, and carotenoids in leaf tissue of garlic increased with increasing foliar spray with zinc. 
AL- ESAILY 
In the same of data in Table 4 showed that the foliar spray with boric acid at rates150 mg/ 1 marked significant effect of photosynthetic pigments of strawberry leaves as compared to other treatments.

It is obvious from data in Table 5 that the interaction between zinc and boron application had significant effect on chlorophyll $\mathrm{a}, \mathrm{b}$ and total $(\mathrm{a}+\mathrm{b})$ as well as carotenoids in the leaf tissues of Strawberry plants. Foliar spray with 150 mg $1 \mathrm{ZnSO}_{4}+150 \mathrm{mg} / \mathrm{l}$ boric acid $(17 \% \mathrm{~B})$ recorded the highest values of chlorophyll $\mathrm{a}, \mathrm{b}$, total $(\mathrm{a}+\mathrm{b})$ and carotenoids in the leaf tissues in both seasons, whereas, application ( $0 \%$ ) gave the lost values in both seasons.

\section{NPK contents in branches and fruits:}

The effect of foliar application with 150 and $200 \mathrm{mg} / 1 \mathrm{ZnSO}_{4}, 100$ and $150 \mathrm{mg} / 1$ boric acid $(17 \% \mathrm{~B})$ and different combination treatments among them as well as water spray (control) on mineral contents (NPK) in branches and fruits of strawberry plants. It is obvious from the data that foliar application of $\mathrm{Zn}$ and $\mathrm{B}$ at all concentrations reflect significant effect on all mineral contents (NPK) in plants as compared to control (water spray).

It is clear from data in Table 6 that the foliar spray with $\mathrm{ZnSO}_{4}$ at rates $150 \mathrm{mg} / 1$ a marked significant effect of NPK contents in their branches and fruits as compared to other treatments. These results agreed with those reported by Abedy (2001).

According to Table 6 that the foliar spray with boric acid at rates 150 $\mathrm{mg} / \mathrm{l}$ a marked significant effect of NPK contents in their branches and fruits. These results are in harmony with those reported by Mohamed and Helal (1999) found that spraying broad bean plants with B at a rate of $50 \mathrm{gm} / \mathrm{fed}$ increased $\mathrm{N}$ and $\mathrm{P}$ leaves content.

In the present study according to Table 7 shows that the interaction between zinc and boron had a significant effect on NPK contents in their branches and fruits of strawberry plants. foliar spray with $150 \mathrm{mg} / 1 \mathrm{ZnSO}_{4}+$ $150 \mathrm{mg} / \mathrm{l}$ boric acid recorded the highest values of $\mathrm{N}, \mathrm{P}$ and $\mathrm{K}$ contents in their shoots and fruits except $\mathrm{N}$ content in branches in both seasons. These results agreed with those reported by This may be attributed to plants were health (Table 2) and fruits were good (Table 8), which reflected on enhancing minerals uptake by plants to maximum values, and resulting in maximum accumulation of minerals in plants.

\section{Early and total yield.}

As for the effect of $\mathrm{ZnSO}_{4}$ rates 0,150 and $200 \mathrm{mg} / 1$ and as boric acid rates 0,100 and $150 \mathrm{mg} / 1$ on fruit weight $(\mathrm{gm})$, number of fruit per plant, fruit 
AL- ESAILY 
yield per plant(gm) and fruit yield per fed (ton) both early yield and total yield are presented in Tables 8 and 10. These results show that there were a significant effect to zinc rates and boron rates on fruit weight (gm), number of fruit per plant , fruit yield per plant(gm) and fruit yield per fed (ton) both early yield and total yield.

Concerning the effect of $\mathrm{ZnSO}_{4}$ the obtained results in Tables 8 and 10 indicate that, foliar spray of $\mathrm{ZnSO}_{4}$ at rates $(150 \mathrm{mg} / \mathrm{l}$ as $)$ recorded the maximum values of average fruit weight (gm), number of fruit per plant, fruit yield per plant (gm) and fruit yield per fed (ton) both early yield and total yield except average fruit weight (gm) un significant between foliar spray of $\mathrm{ZnSO}_{4}$ at rates (150 and $200 \mathrm{mg} / \mathrm{l})$ in both seasons. While, Foliar spray of $\mathrm{ZnSO}_{4}$ at rate $(0 \mathrm{mg} / \mathrm{l})$ gave the lost values in both seasons.

Zinc $\left(\mathrm{ZnSO}_{4}\right)$ has an important role either as a metal component of enzymes or as a functional, structural or regulatory cofactor of a large number of enzymes (Bowler et al., 1994). Zinc sulphate induces pollen tube growth through its role on tryptophan biosynthesis, as an auxin precursor (Chaplin and Westwood, 1980). Growth of the receptacle is controlled primarily by auxin, which is synthesized in the achene's, so an application of $\mathrm{ZnSO}_{4}$, a prerequisite of auxin, is potentially useful in increasing fruit size as well as its quality. Therefore $\mathrm{ZnSO} 4$ is applied to increase fruit number, size and quality. These results are in harmony with those reported by Barker and Pilbeam (2006).

Respecting the effect of $\mathrm{B}$, the obtained results in Tables 8 and 10 indicate that, foliar spray of boric acid $(17 \% \mathrm{~B})$ at rate $150 \mathrm{mg} / \mathrm{l}$ recorded the maximum values of average fruit weight (gm), number of fruit yield per plant (gm), fruit yield per fed (ton) both early yield and total yield except average fruit weight (gm) un significant between foliar spray of boric acid at rates 100 and $150 \mathrm{mg} / \mathrm{l}$ in both seasons as well as number of fruit yield per plant (gm) in first season only. While, foliar Spray of boric acid at rate $(0 \mathrm{mg} / \mathrm{l})$ gave the lowest values in both seasons. These results are in harmony with those reported by Jana et al.(1987), Padma et al. (1989)

With regard to the interaction, data in Tables (9 and 11) show that the interactions between $\mathrm{ZnSO}_{4}$ and boric acid as foliar spray had significant effect on average fruit weight (gm), number of fruit per plant, fruit yield per fed (ton) both early and total yield of Strawberry plants. foliar spray with $150 \mathrm{mg} / \mathrm{l}$ $\mathrm{ZnSO}_{4}+150 \mathrm{mg} / \mathrm{l}$ boric acid recorded the highest values of average fruit weight (gm), fruit yield per plant (gm), fruit yield per fed (ton) in both early and total yield except, number of fruit per plant early yield un significant in both seasons. As well as number of fruit per plant total yield in first season. 
AL- ESAILY 
AL- ESAILY 
Among nutrients, zinc and boron play an important role in pollination, fruit set, and total yield (Motesharezade et al., 2001). Boron $\left(\mathrm{H}_{3} \mathrm{BO}_{3}\right)$ is an essential element required for optimal growth and development in higher plants (Marschner, 1995). Increased fruit yields in pear and sour cherry have been reported using B fertilization (Wojcik and Wojcik, 2003).

\section{Fruit quality:}

Data in Table 12 represent the effect of $\mathrm{ZnSO}_{4}$ rates 0,150 and 200 $\mathrm{mg} / \mathrm{l}$ and boric acid rates 0,100 and $150 \mathrm{mg} / \mathrm{l}$ on fruit quality (vit. C, TSS, reducing sugar, total sugar and total acid in fruit) of strawberry, it is evident that all treatments had a positive effect on Vit. C, TSS, reducing sugar, total sugar and total acid in fruit under study in two growing seasons. Concerning the effect of zinc rates, there were a significant difference between the effect of zinc rates, and plants sprayed with $150 \mathrm{mg} / \mathrm{l} \quad \mathrm{ZnSO}_{4}$ gave the highest values of Vit. C, TSS, reducing sugar, total sugar and total acid in fruit as compared to other treatments. $\mathrm{ZnSO} 4$ claimed that a foliar spray application of $\mathrm{ZnSO}_{4}$ on March and April increased size, TSS and juice of oranges. Zinc has also shown to have an important role in photosynthesis and related enzymes, resulting in increasing sugar and decreasing acidity (Abedy, 2001). These results agree with reported with Rath et al., (1980) who reported that foliar application of zinc sulfate $(0.8 \%)$ increased vitamin $\mathrm{C}$.

The effect of boric acid rates at 0,100 and $150 \mathrm{mg} / \mathrm{l}$ on fruit quality (Vit. C, TSS, reducing sugar, total sugar and total acid in fruit) of strawberry are illustrated in the same Table. Results revealed that spraying plants with 150 $\mathrm{mg} / \mathrm{l}$ boric acid significantly improved on fruit quality.

These results could be attributed to the effect of $\mathrm{Zn}$ and boron on the increase of nutrient absorption and photosynthesis process that lead to more accumulation of metabolism in reproductive organs, which in turn improve fruits quality of strawberry (Hagreaves et al., 2009). Adding boron as foliar spraying plays a key role in improve size of fruits and stimulates fruits color. It is necessary for the translocation sugar and formation of carbohydrates consequence increase fruits quality

Data in Table 13 showed that significant differences were observed among treatments as far as vitamin $\mathrm{C}$, is concerned and highest vitamin $\mathrm{C}$, TSS and total sugar was observed in concentrations of $\mathrm{ZnSO}_{4}$ at $150 \mathrm{mg} / 1+$ boric acid at $150 \mathrm{mg} / \mathrm{l}$.Whereas, the interaction between $\mathrm{Zn}$ and $\mathrm{B}$ have non significantly on reducing sugar in both seasons. 
AL- ESAILY 
Conclusively, result showed that spraying strawberry plant with 150 $\mathrm{mg} / \mathrm{l} \mathrm{ZnSO}_{4}$ or $150 \mathrm{mg} / \mathrm{l} \mathrm{H}_{3} \mathrm{BO}_{3}$ significantly increased all studied parameters, such as vegetative plant growth, early and total yield, as well as, fruit quality in both seasons as compared to control treatment $(0 \mathrm{mg} / \mathrm{l})$, which recorded the lowest values of all studied parameters. In generally, spraying plants with 150 $\mathrm{mg} / 1 \mathrm{ZnSO} \mathrm{O}_{4}+150 \mathrm{mg} / \mathrm{H} \mathrm{H}_{3} \mathrm{BO}_{3}$ gave the best results for increasing plant growth, yield and its components, as well as, fruit quality, i.e., Vit. C, TSS and total sugar in both seasons as compared other interaction treatments.

\section{REFERENCES}

A.O.A.C. (1995) Official systems of analysis. $17^{\text {th }}$. ed. A.O.A.C., Wash., D.C. Abdollahi1, M. , S. Eshghi and E. Tafazzoli (2010). Interactive of paclobutrazol, boron and zinc on vegetative growth, yield and fruit quality of Strawberry ( Fragaria x Ananassa Duch. cv. Selva). J. Biol. Environ. Science, 14 (11): 67-75

Abdollahi1, M. ; S. Eshghi; E. Tafazzoli and N. Moosavi (2012). Effects of paclobutrazol, boric acid and zinc sulfate on vegetative and reproductive growth of Strawberry cv. Selva. J. Agr. Science Tech., 14: 357-363.

Abedy, A. (2001). Effects of zinc sulfate and citric acid spray on fruit characteristics of tomato cultivar Urbana'. M.. Sc. Thesis, Shiraz University.

Ahmad, O. M. (2002). Physiological studies on garlic crop. M. Sc. Thesis, Faculty Agriculture, Zagazig University, Egypt.

Archbold, D.D. and F.G. Dennid (1984). Quantification of free ABA and conjugated IAA in strawberry achene and receptacle tissue during fruit development. J. Amer. Soc. Hort. Science, 109: 330-335.

Barker, A.V. and D.J. Pilbeam ( 2006 ). Handbook of plant nutrition. CRC Press, London, New York. Battal, P., 2004. Effects of some mineral nutrients on gibbrellic acid levels in maize plants. Economic Botany, 58(2): 195-203.

Bowler C., W. Vancamp; M. Vanmontagu and D. Inze (1994). Superoxidedismutase in plants. Critic. Rev. Plant Science, 13 (3), 199-218.

Chaplin, M.H. and M.N. Westwood (1980). Relationship of nutritional factors to fruit set, J. Plant Nut., 2(4), 477-505.

El-Sayed, H. A. (1991). Effect of Fe, Mn, Zn and B on the growth and yield of snap bean plants. J. Agric. Science, Mansoura University, 16(2) 402-406.

F.A.O. (2010). Food and Agricultural Organization. Statistics of strawberry production in Egypt. 
Forsee, W.T.J. (1938). Determination Of Sugar In Plant Materials A Photometeric Both Method. Indus. Eng. Chem. Annual, Ed. 10:411-418. Journal Plant Nutr. , 22(10), 1651- 1664.

Hagreaves, J. C.; M. S. Adi and R. R. Warman (2009). The effects of municipal solid waste compost and compost tea on mineral element uptake and fruits quality of strawberry. Compost Science and Utilization, 17(2)85-94.

Jana, B.; K. Jahangir- Kabir and J. Kabir (1987). Influence of micronutrients on growth and yield of french bean $c v$. Contender under polyhouse conditions. Vegetable Science, 14 (2) 124-127.

Kabata A. and H. Pendias (1992). Trace Elements In Soils And Plants. $2^{\text {nd }}$ ed. CRC Press, Boca Raton Ann. Arbor, London, pp. 365.

Marschner, H. (1995). Mineral Nutrition of Higher Plants. 2nd edition, Academic Press, London. 889 pp. J. Biol. Environ. Science, 2010, 4(11), 67-75.

May, G. M. and M. P. Pritts (1993). Phosphorus, zinc, and boron influence yield components in 'Earliglow'strawberry. Journal Amer. Soc. Hort. Science, 118(1), 43-49.

Mohamed , F. I. and F. E. Helal (1999). Effect of planting method and foliar spray with manganese, zinc, boron and iron on growth, green yield and its components and chemical content of broad bean plants. Minufiya $J$. Agric. Ref., 24 (3) 1033-1045.

Motesharezade, B.; M. J. Malakuty and B. Nakhoda (2001) Effects of N, Zn and B sprays on photochemical efficiency of sweet cherry. Hort Newsletter, 12: 106- 111.

Padma, M.; S. A. Reddy and R.S. Babu (1989). Effect of foliar sprays of molybdenum (Mo) and boron (B) on flowering, fruiting and yield of French bean (Phaseolus vulgaris L.). J. Res. Apau, 17 (2):145-149.

Rath S.; R. B. Singh and D.B. Singh (1980). Effect of boron and zinc sprays on physic - chemical composition of mango fruits. Punjab Hort. Journal, 20: 33- 35. (Abstract).

Reddy, T. Y. and G. H. S. Reddi (1998). Principles Of Agronomy. Kalyani Publishers Ludhiana, New Delhi, India, pp. 515.

Sadasivam S . and Thymoli B. (1987). (in) Practical Manual in Biochemistry, pp 14. Tamilnadu Agricultural University Coimbtore.

Snedecor, G. W. and W. G. Cochran (1980). Statistical Methods. $7^{\text {th }}$ ed. Iowa State University, Press Ames., Iowa, U.S.A.

Srivastava, P.C. and U.C. Gupta (1996). Trace Elements In Crop Production. Science Pub. Inc. Lebanon, N.H. 03766 USA pp.365. 
Wettestein, D. (1957). Chlorophyll. Lethale under submikross - kopische formwechesl der plastiden. Exptl. Cell. Research, $12:$ 427-433.

Wojcik, P. and M. Wojcik (2003). Effect of Boron Fertilization on 'Conference' Pear Tree Vigor, Nutrition, and Fruit Yield and Storability. Plant Soil, 256: 413-421.

Zuhair A. Dawood Ayad H. Al-Alaf Ragheed H. Al-Sultan(2010). Effect of foliar application of boron on growth, flowering and yield of strawberry. Iraq Agriculture Science, 1(3):1-10.

\section{تأثير الرش الو رقى بالزنك والبورن على النمو والمحصول وجودة ثمار

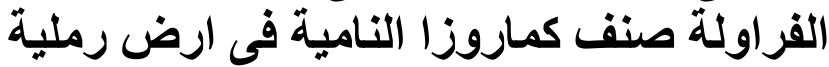

$$
\text { معهد بحوث البساتين مركز البحوث الله سليم العيلية الجيلي الجيزة- مصر. }
$$

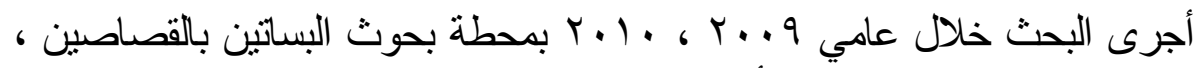

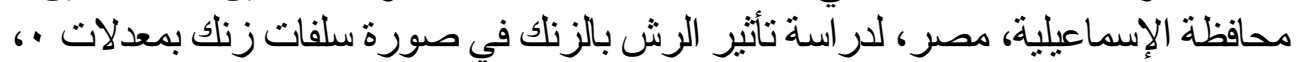

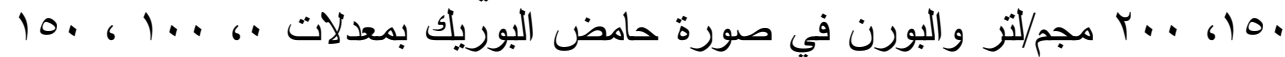
مجم/لتر على النمو الخضري وصبيخات البناء الضوئي والمحتوى الكيماوي بالأفرع و الثمار و الإنتاجية لمحصول الفراولة النامي تحت ظروف الار أضى الرى الرملية مع نظام الري بالتنقيط.

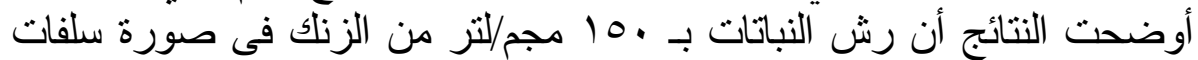

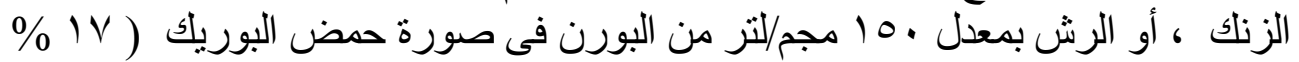

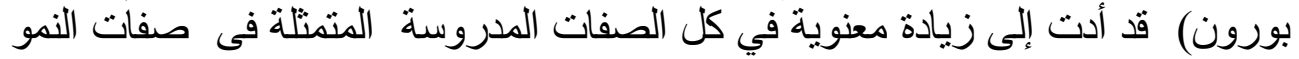

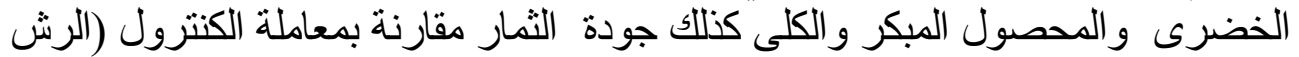

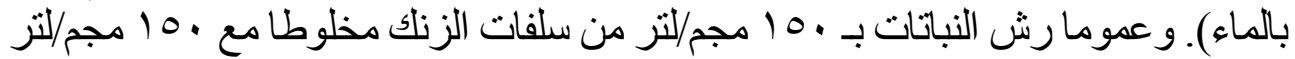

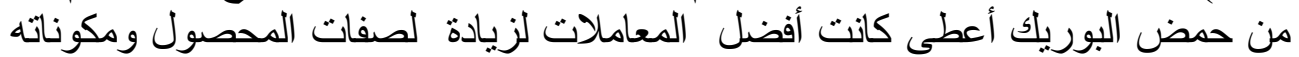

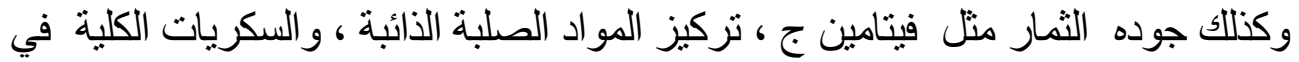
الموسمين مقارنة بباقي معاملات التفاعل. فئل فئل

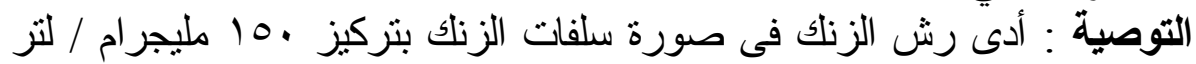

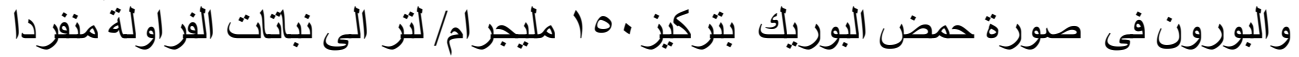
أو فى مخلوط الى تحسن صفات النمو الخضرى و والمحصول وجودة الثمار عند الحصاد. 